\title{
AN ERROR ANALYSIS IN USING SIMPLE PAST TENSE IN INCIDENT REPORT E- MAILS BY KIDS CLUB SOFITEL STAFF
}

\author{
I Gusti Ngurah Bagus Yoga Widiadnya \\ Program Studi Sastra Inggris, Fakultas Sastra, Universitas Teknologi Indonesia, \\ yogawidiadnya16@gmail.com
}

\begin{abstract}
This research aimed to find out the common errors of word order especially in using verb, to be, and noun phrase in writing incident report emails made by Kids club Sofitel staffs. The problem statement of this research was "what are the types and the sources of error on the use of simple past tense in Kids club incident reports by email writing". The objective of this research was to find out the types and the sources of errors that often occurred in the use of simple past tense in incident reports made by Kids club Sofitel staffs. To analyze the data, the researcher used descriptive qualitative method and used error analysis procedure to make clear explanation. The error collected was classified based on Dulay Strategy Taxonomy. The participants of this study consist of five staffs from Kids club Sofitel Bali Nusa Dua. By this analysis, the researcher found errors as follows: there were 132 errors were found in the staff's incident reports. The total errors of Omission were 64 errors, Addition were 5 errors and Mis-formation were 63 errors and also 109 errors of Intralingual transfer and 23 errors of Interlingual transfer. So could be concluded that the most of error found was Omission and lowest of error found was Addition and the most of sources of error was Intralingual transfer.
\end{abstract}

Keywords: Error Analysis, Simple Past Tense, E-mail.

\begin{abstract}
Abstrak
Abstrak. Penelitian ini bertujuan untuk mengetahui kesalahan umum urutan kata terutama dalam menggunakan kata kerja, menjadi, dan frasa kata benda dalam menulis email laporan kejadian yang dibuat oleh staf Kids club Sofitel. Pernyataan masalah dari penelitian ini adalah "apa jenis dan sumber kesalahan tentang penggunaan simple past tense dalam laporan insiden Kids club dengan menulis email". Tujuan dari penelitian ini adalah untuk mengetahui jenis dan sumber kesalahan yang sering terjadi dalam penggunaan simple past tense dalam laporan insiden yang dibuat oleh staf Kids club Sofitel. Untuk menganalisis data, peneliti menggunakan metode deskriptif kualitatif dan menggunakan prosedur analisis kesalahan untuk membuat penjelasan yang jelas. Kesalahan yang dikumpulkan diklasifikasikan berdasarkan Dulay Strategy Taxonomy. Peserta penelitian ini terdiri dari lima staf dari Kids club Sofitel Bali Nusa Dua. Dengan analisis ini, peneliti menemukan kesalahan sebagai berikut: ada 132 kesalahan ditemukan dalam laporan insiden staf. Total kesalahan Kelalaian adalah 64 kesalahan, Penambahan 5 kesalahan dan Kesalahan informasi adalah 63 kesalahan dan juga 109 kesalahan transfer Intralingual dan 23 kesalahan transfer Interlingual. Jadi dapat disimpulkan bahwa sebagian besar kesalahan yang ditemukan adalah Kelalaian dan kesalahan terendah yang ditemukan adalah Penambahan dan sebagian besar sumber kesalahan adalah transfer Intralingual.
\end{abstract}

Kata kunci: Analisis Kesalahan, Simple Past Tense, E-mail.

\section{INTRODUCTION}

English language has played an important role in the world of information and technology. Skills in learning English that commonly known are; listening, speaking, reading and writing. From these four skills, it can be understood which one is the basic, the hardest, and the most complex skill. Writing has been claimed as the hardest skill because the students are required to master the four types of knowledge; knowledge of the content, procedural knowledge to organize the content, knowledge of conventions of writing and procedural knowledge for integrating all the other types of knowledge. Writing in English 
language is a great challenge for the students and the other people. It's true that some staffs still have difficulties in writing since they lack vocabulary, spelling and grammar. According to Saragih, Silalahi, and Pardede (2014), "Writing is difficult for the students because they lack vocabulary, spelling, and grammar" (p.56). Since English language has been and still be the main form of business communication around the world, being able to use English well can be a major advantage for everyone. While being a fluent English speaker is a primary requirement in many professional fields, English language writing skills are also important as written English is the only way to communicate when oral communication is not possible.

Then, according to Dundalk Institute of Technology (2015) defined that "An Accident is defined as an unplanned event resulting in personal injury or property damage". An incident report is a formal recording of the facts related to an incident. The report may pertain to any unusual occurrence on a worksite, but would normally relate to an accident or injury that has occurred. Ideally, the incident report should be completed as soon as possible following the injury. Depending on the severity of the incident, the report may be used solely by the company for future safety planning, or it may go to insurers, the overseeing regulatory body or the police. Any incident that involves worker safety should be recorded, no matter how insignificant it may seem. An investigation of what happened should be undertaken as soon as possible after the incident occurs and after the injured person has been taken care of.
At Sofitel Kids Club, they use E-mail to report any kind of business especially incident of the guest which is should be reported to the head of department. According to Chapman (2007), e-mail content should be concise, conclusive, and error free. Any e-mail content that contains misspellings or grammatical errors can be considered as unprofessional which would affect the image of the writer and can negatively affect any business as it can cause misunderstanding. Therefore, good writing skill is required because without it misunderstanding can occur and what is to be communicated can be misunderstood.

Correctness in writing is important and it has therefore become one of the major concerns among education policy makers who wish to encourage teachers to implant the idea of the importance of correctness in writing English among learners (Barber, 2006). Writing quality can affect the image of the writers giving the impression that they are either professional or unprofessional, detail-oriented or not attentive. Good writing skill is required in the world of globalization where communication is not limited only to speaking. Since Kids Club staffs often make the mistake that led to grammatical errors in their emails writing, researcher wants to analyze kind of errors on the use of simple past tense which is made by Kids Club Sofitel Staff in Incident Report Emails writing, the mistake was not rejected, but it will be an evaluation for consideration to not make the same mistakes in other occasions. 
Based on the background above the researcher identified the problem as follows; what are the sources of errors found on the use of simple past tense in Kids Club incident reports by email writing? Also what are the types of errors on the use of simple past tense in Kids Club incident reports by email writing?

The result of this research is expected to be able to give the following benefits; First, for the Readers; the researcher hopes that this research study can help to enriching the readers' knowledge and experience in the scientific research especially in using simple past tense, also can be used to help the readers in writing and practice in daily conversation. Second, for Kids Club Staffs; they may know their mistakes in writing simple past tense and also the correction, so that they can make a better writing of incident report for the future, especially in incident report to make any evaluation to the staff's errors related to their weaknesses in simple past tense. Third, For Other Researchers; the results of this study are expected to be one of resources the other researchers to conduct similar research which can be a compare matter and to make their English better.

\section{Research Method}

This research aimed at investigating grammatical errors, specifically the wrong used of simple past tense which occurred in e-mail content, produced by Sofitel kids' club staffs. A qualitative descriptive approach was used to identify the types of errors and their sources.
The researcher worked on identifying, classifying/categorizing, and explaining the errors in using simple past tense. The data was collected from the e-mail contents, directly sent, carbon copied (CC), and blind carbon copied (BCC) to the researcher. The researcher identified all errors in using simple past tense which occurred in the email content and then categorized the errors into specific categories. The e-mails which were used for the analysis were randomly selected from 10 incident report emails from the total of 30 emails, around 20 months between October 2016 to June 2018 . The researcher randomly selected the contents as to avoid taking too much time to analyze. Permission was obtained from Human Resources Department and IT Department.

The data analysis was started after all the incident reports collected. The next step in analyzing staffs' errors was identification of the errors. The identification was done by reading the incident report, if the sentences contained errors, they were classified according to the error type's taxonomy and underlying the errors. The researcher categorized the errors found in the study, based on the adaptation of the surface strategy taxonomy. The error types were; Omission, Addition, Misformation, Misordering. The errors found in the incident report emails were classified into the mentioned categories.

\section{Result}

This research was analyzed based on Dulay et all theory, the surface strategy taxonomy which concerns on omission, 
addition, misformation, and misordering errors. To find out the types of errors and how many errors on those components, the researcher documented the incident report emails. And also the sources of errors were counted. The last step was counting each type of errors and its sources. The total errors of Omission were 64 errors, Addition were 5 errors and Misformation were 63 errors and also 109 errors of Intralingual transfer and 23 errors of Interlingual transfer. Some examples are;

(Email 10) the sentence of misformation error "... and so we are looking at pool" it should be: "... and also we looked at the pool" in simple past tense sentence we should use the Verb 2.

Error of omission example: *His parent fine. While she was supposed to write, His parents were fine. From the example above it was clear that the staffs did not use an article and a verb.

In Addition the researcher found: (Email 7) *Tala was came at 12.20pm. The word "was" there must be omitted because it was not needed. As we know that the simple past tense form only used verb two. So that the right answer was supposed to be "Tala came at $12.20 \mathrm{pm} "$.

In interlingual error, this source of error could be called errors by negative transfer. The example was (Email 6) "that they a medicine”. The correct one was “...that they had a medicine.". (Email 2) "When he a little run.", It should be "When he did a little run.", "Inform you that an accident today", it should be "Informed you that we had an accident today". These errors happened because the pattern of Both Bahasa - which was their mother tongue- and English were totally different.

In intralingual error, interference from the staffs' own language was not the only reason for committing errors. (Email 3) the sentence "When we give them...", it should be "When we gave them". (Email 7) the sentence "Fall at the trampoline", it should be "Fell at the trampoline”. "Mrs. Efranian also tell us". It should be "Mrs. Efranian also told us".

The staffs used the wrong form of simple past tense, so the researcher assumed that the error caused by interlingual and intralingual transfer because Bahasa had different grammatical rules from English. The kids club staffs made errors in producing verb two in past form. They failed to recognize changed verb one to verb two in regular and irregular verbs.

\section{Conclusion}

Based on the finding and discussion of the data in the research, the researcher found there were 132 total errors that made by the Kids Club Sofitel staffs. Those errors derived from omission with 64 errors, misformation with 63 errors, and addition with 5 errors. The researcher found there were two main sources why the errors happened that was from Interlingual transfer and Intralingual transfer they were classified to 112 errors of Intralingual Transfer and 20 errors of Interlingual Transfer. So, after analyzed the errors, the types of error, and the sources of error. The researcher concluded that some of the kids' club staffs still 
faced some difficulties on using the correct form of simple past tense. From five staffs and 10 selected emails, the researcher concluded that the most types of error found was Omission and the most sources of error found was from Intralingual transfer. It meant that these errors happened because some of the kids' club staffs had lack of gramatical rule in English simple past tense.

\section{REFERENCES}

A, Syams, N. F., Faculty, T. H. E., Tarbiyah, O. F., \& Training, T. (2016). ERROR ANALYSIS OF WORD ORDER USED IN WRITING RECOUNT TEXT MADE BY STUDENTS' AT SMK NEGERI 1 PINRANG THE FACULTY OF TARBIYAH AND TEACHER TRAINING.

Bustomi, A. (2009). an Error Analysis on Students, Descriptive an Error Analysis on Students 'Descriptive, 83183.

Carlos, S. (2017). Linguistic Error Analysis on Students' Thesis Proposals Mary Ann Pescante-Malimas and Sonrisa C . Samson. 3(2).

DUNDALK. (2015). Accident, Incident, Near Miss and Dangerous Occurrence Reporting.

Education, I., \& Faculty, T. T. (2017). AN ERROR ANALYSIS ON THE USE OF SIMPLE PRESENT TENSE IN WRITING DESCRIPTIVE TEXT A . Introduction. 4(2), 1-17.

Email, L. (2014). an Error Analysis on the Use of Conjunctions in the Writing By Freshmen At Pre-Intermediate, 1-11.

Independent, A. N., Paper, S., In, S., Of, F., Requirements, T. H. E., The, F. O. R., ... Foreign, A. S. A. (2015). $A N$ ANALYSIS OF ERRORS IN SIMPLE PAST TENSE IN E-MAIL WRITING BY HOTEL STAFF AN ANALYSIS OF ERRORS IN SIMPLE PAST TENSE IN

\section{E-MAIL WRITING BY HOTEL STAFF.}

Mega, P. (2017). An Error Analysis On The Use of Past Tense In Narrative Text, 1-11.

Miftahul, M., \& Habibullah, K. (2010). an Error Analysis on Grammatical Structures of the Students' Theses English Letters Department Faculty of Letters and Humanities Syarif Hidayatullah State Islamic University Jakarta 2010.

NURWAHYUNI. (2017). AN ERROR ANALYSIS OF THE PUNCTUATION IN STUDENTS' WRITING (A Study at Sixth Semester Students of English Department of UIN Ar-Raniry).

SUSANTO, I. (2016). AN ERROR ANALYSIS ON SUBJECT-VERB AGREEMENT FOUND IN HORTATORY EXPOSITION TEXTS WRITTEN BY WRITING 3 STUDENTS OF ENGLISH DEPARTMENT. (1213012058).

Schillinger, B. B., \& Schillinger, B. B. (1981). Error analysis: beyond the basic writer.

Skripsi, a, \& Fahruroji, O. J. I. (2010). an Error Analysis on Students 'Difficulties in Department of English Education Faculty of Tarbiyah and Teachers Training State Islamic University an Error Analysis on Students Difficulties in Department of English Education State Islamic University.

Thesis, A., Syams, N. F., Faculty, T. H. E., Tarbiyah, O. F., \& Training, T. (2016). Error Analysis of Word Order Used in Writing Recount Text Made By Students' At Smk Negeri 1 Pinrang the Faculty of Tarbiyah and Teacher Training. 